\title{
Austerity and the Rise of the Nazi Party
}

\author{
Gregori Galofré-Vilì̀, Christopher M. Meissner, \\ Martin McKee, and David StUCKLER
}

\begin{abstract}
We study the link between fiscal austerity and Nazi electoral success. Voting data from a thousand districts and a hundred cities for four elections between 1930 and 1933 show that areas more affected by austerity (spending cuts and tax increases) had relatively higher vote shares for the Nazi Party. We also find that the localities with relatively high austerity experienced relatively high suffering (measured by mortality rates) and these areas' electorates were more likely to vote for the Nazi Party. Our findings are robust to a range of specifications including an instrumental variable strategy and a border-pair policy discontinuity design.
\end{abstract}

I n 1928, the German Nazi Party earned just over 2 percent of the votes in the general federal elections. By mid-1932, it had received 38 percent of votes in the national elections, becoming the largest political party in the Reichstag. How did this shift to the extreme far-right happen so quickly? Economic factors, such as high unemployment associated with the Great Depression, sociocultural issues, and the excessively punitive Treaty of Versailles, are well studied. They undoubtedly played an important role in the rise of the Nazi Party. Still, the rapid growth of support for the Nazi Party well into the Great Depression remains the subject of considerable

The Journal of Economic History, Vol. 81, No. 1 (March 2021). (C) The Author(s), [2021]. Published by Cambridge University Press on behalf of the Economic History Association. This is an Open Access article, distributed under the terms of the Creative Commons Attribution licence (http://creativecommons.org/licenses/by/4.0/), which permits unrestricted re-use, distribution, and reproduction in any medium, provided the original work is properly cited. doi: 10.1017/ S0022050720000601.

Gregori Galofré-Vilà is Assistant Professor, Universidad Pública de Navarra, Department of Economics, and Institute for Advanced Research in Business and Economics. E-mail: gregori. galofre@unavarra.es. Christopher M. Meissner is Professor, Department of Economics, University of California, Davis, and Research Associate at the NBER. E-mail: cmmeissner@ ucdavis.edu. Martin McKee is Professor, Department of Health Services Research and Policy, London School of Hygiene \& Tropical Medicine. E-mail: martin.mckee@1shtm.ac.uk. David Stuckler is Professor, Department of Social and Political Sciences, University of Bocconi. E-mail: david.stuckler@unibocconi.it.

Earlier versions of this paper were presented at the Australian National University, Hitotsubashi University, Humboldt University, the NBER, New York University, New York UniversityShanghai, Shanghai University of Finance and Economics, UC Berkeley, UC Davis, UC Irvine, UCLA, the University of Groningen, the University of Michigan, and the 2018 World Economic History Congress. We thank Maja Adena, Barbara Biasi, Fabio Braggion, Barry Eichengreen, Ruben Enikolopov, Sanford Jacoby, Harold James, Peter Lindert, Dan Liu, Petra Moser, Maria Petrova, Burkhard Schipper, Nico Voigtländer, Hans-Joachim Voth, and Noam Yuchtman for a series of constructive suggestions. We also thank the editor, Dan Bogart, and four anonymous referees for comments. DS is funded by a Wellcome Trust and European Research Council Investigator Award (ERC HRES 313590). 
debate (Eichengreen 2018; Ferguson 1996; James 1986; Satayanth et al. 2017; Temin 1990; Voth 2020).

In this paper, we investigate the association between the austerity measures implemented by the German government between 1930 and 1932 and voters' increased support for the Nazi Party. A growing literature studies the interactions between political preferences and fiscal policy with evidence that austerity packages are correlated with rising extremism (Alesina, Favero, and Giavazzi 2019; Bor 2017; Eichengreen 2015, 2018; Fetzer 2019; Ponticelli and Voth 2020). It stands to reason that the austerity measures implemented in Germany in the early 1930s played a role. However, we are aware of no direct quantitative assessment of this issue for the Weimar Republic.

During this period, Heinrich Brüning of the Center Party, and Germany's chancellor between March 1930 and May 1932, implemented a set of measures via executive decree in order to balance the country's finances. These austerity measures included real cuts in spending and transfers as well as higher tax rates. Brüning believed that the consequent suffering would be highly visible, thereby eliciting international sympathy for the Germans and helping put an end to the unpopular reparations imposed at Versailles (Evans 2003).

To test the hypothesis that austerity can explain increased Nazi vote share, we use city and district-level election returns for the federal elections of 1930, 1932 (July and November), and 1933. We then link local vote shares to different proxies for city, district, and state-level fiscal policy changes while also controlling for other potential explanations for the rise of the Nazis, such as unemployment, changes in wages, and economic output. Our results are robust to inclusion of a number of different controls and specifications including city-level time trends, state by year fixed effects, and electoral district by year fixed effects.

The observational data we use to study austerity and extremism have a number of features that enable us to overcome obvious issues of reverse causality and endogeneity. Brüning's policies on spending and taxes were not expected. Instead, they became an outcome of the unexpectedly severe economic and financial crisis. They were decided at the Reich level by Brüning and his cabinet with implicit support of the Reichstag. Spending cuts and tax increases were uniformly applied across the nation so that the policy decisions were exogenous to the preferences of specific cities and districts. As noted by Balderston (1993, p. 225), "the progressive 'nationalization' of taxing and spending decisions, justifies historians in the responsibility they place on the Brüning cabinet and on Brüning personally, for the fiscal balance during the slump." 
Limits on spending and on changes to taxes, policy variables often formerly controlled by local authorities, were also imposed. Successive pay cuts to national civil service salaries are an example. Although some expenditure cuts were out of the hands of localities and mandated by the national government, some budget categories were hit harder than others. This fact means that nationally imposed budget cuts might have differential impacts on localities depending on the predetermined patterns of spending and reliance on the national government for transfers to fund different categories of spending. We use city-level variation in the preausterity reliance on Reich transfers and national changes in transfers as a shift-share instrumental variable for subsequent spending declines. Since states, localities, and the central government were unable to borrow on international capital markets after 1930 (Schuker 1988), localities were forced by markets to traverse the depression with highly disruptive fiscal shocks.

As for taxes, a similar logic applies. The Reich maintained control over a number of specific taxes, determining, for example, the statutory marginal rates for income taxes and corporation turnover taxes. Changes to the statutory marginal rates applied equally and evenly to all states and localities, but lower brackets had higher percentage increases in income tax rates (Newcomer 1936). We use variation at the local level in the initial distribution of taxable income across tax brackets and national changes in tax policy to instrument for the austerity-driven tax hikes. To make identification valid, we need to avoid confounding our fiscal shock with an unobservable economic shock correlated with income distribution. On the income distribution, Dell (2007) and Gómez-León and de Jong (2019) show that Gini coefficients and top income shares were fairly constant between 1928 and 1933.

Higher Nazi vote share could be because of resentment arising from distributional battles for slices of the fiscal pie in difficult times. There is clearly a distributional component to these changes, the percentage rise in tax rates being much higher for the lower income brackets. Wueller (1933) also discusses that while tax revenue had traditionally been retained where it was collected, intrastate redistribution was increasingly becoming need based during the Depression.

We also use a number of different econometric specifications to eliminate further concerns about endogeneity. We employ both city/district fixed effects models and long differences to focus on within-locality variation in Nazi support. We are also able to circumscribe the control group by matching districts to neighboring districts just across state borders, as in Dube, Lester, and Reich (2010). While relevant observables were spatially smooth, fiscal policy across the state borders was sharply different because 
state policies responded to statewide concerns. With this identification strategy, we are also able to control for common economic shocks correlated with the initial characteristics of localities by using period by districtpair fixed effect interaction terms. Even after controlling for local economic shocks between 1930 and 1932 in this way, austerity remains a statistically, economically, and politically significant determinant of Nazi vote share.

We also provide some novel quantitative estimates concerning the channels by which austerity mattered. To do so, we study the relationship between mortality rates and austerity. We find a plausible link, since where public spending on health care dropped more, mortality was higher. These places also saw a relatively large increase in Nazi support at the polls. Finally, looking at archival documents of Nazi propaganda, we document how Nazi leaders invoked austerity to attack Brüning and the Weimar Republic and how Brüning's tax rises were seen as inefficient and unfair by the German masses.

Even though there has been a German debate on whether there was an alternative to austerity (Borchardt 1980; Büttner 1989; Ritschl 1998; Voth 1993) and speculation that austerity played a role in the rise of the Nazi Party, to our knowledge, no previous research has directly tested the quantitative impact and the channels by which fiscal austerity mattered. Falter, Lindenberger, and Schumann (1986), Frey and Weck (1981), King et al. (2008), and Stögbauer and Komlos (2004) studied the economic shocks of the period, but they did not use fiscal data and the transmission mechanisms emphasized are different from ours. Previous work focused on a direct channel from lower disposable incomes and unemployment to frustration at the polls. On global comparisons, one study evaluated the impact of the Great Depression and austerity on voting patterns in 171 elections in 28 countries (Bromhead, Eichengreen, and O'Rourke 2013) and another looked at the European level (Ponticelli and Voth 2020). Yet, these have not considered the particular context of Weimar Germany.

Regarding the connection between political competition and differential effects of the crisis, the literature notes that the lowest status groups and the unemployed turned to the Communists (Falter, Lindenberger, and Schumann 1986; King et al. 2008) but those just above in the economic hierarchy, who had more to lose from the tax hikes and spending cuts, seemed to favor the Nazis. Between 1930 and 1933 the Nazis gained votes from all walks of life. Yet, Evans (2003), Falter, Lindenberger, and Schumann (1986), King et al. (2008), and Voigtländer and Voth (2019) have documented how the party was "underrepresented" among the working classes, in industrial cities, and in Catholic regions. We control for these fixed factors and allow for interactions between them and our measures of austerity. 
Our baseline results show that Brüning's austerity had a sizable effect. Each one-standard-deviation increase in austerity was associated with between one quarter to one half of one standard deviation of the dependent variable. In localities where austerity was more severe, Nazi vote share was significantly higher. Our novel use of within-locality variation in the size of the fiscal shock sheds light on the local and national experience of democratic decline.

The rest of the paper is organized as follows. In the next section, we provide a detailed account of the main existing explanations for the rise of the Nazis. The third and fourth sections, respectively, review how austerity was implemented and present the historical context of the different elections in Germany between 1930 and 1933. In the fifth and sixth sections, we show our main results and robustness checks for the city- and district-level outcomes using spending and tax data. The final section concludes.

\section{COMPETING EXPLANATIONS}

There are many competing explanations for the stark rise of the Nazi Party in Weimar Germany. The conventional explanation is the impact of the Great Depression. Those hit hardest by the economic downturn held the incumbent parties responsible for their situation, punishing them by voting for the Nazi Party. Economic activity peaked in Germany in 1928, driven by a sharp downturn in investment (Ritschl 2002; Temin 1971). Later, the cessation of capital inflows and a crisis in the German banking sector culminated in a slowdown in the growth of credit, while other international shocks prolonged the downturn. Yet, the unwillingness of the Reichsbank to stop the deflation mattered but cannot necessarily explain regional variation in Nazi support.

A similar point could be made with respect to the increasing numbers of unemployed workers, soaring from 1.4 million in 1928 to 5.6 million in 1932. Unemployment also reached very high levels in other countries, such as the United States, around that time, without being accompanied by electoral radicalization (Eichengreen and Hatton 1988). Additionally, the unemployed were more likely to vote for the Communist Party or the Social Democrats (in Protestant precincts) rather than the Nazi Party (Evans 2003; King et al. 2008), as the Communist Party was perceived as the party that traditionally represented workers' interests.

A third explanation invokes resentment about high debt repayments imposed on Germany in the Treaty of Versailles. These debts initially totaled up to 260 percent of 1913 GDP (Ferguson 1997; Ritschl 2013). 
Although France and Britain had war debt burdens similar to Germany, the Versailles agreements treated Germany as a conquered enemy, forcing it to pay a large share of the allies' costs of the war. This placed financial demands on Germany that were very difficult to meet and that were dubbed as "cruel" by some (Keynes 1920; Temin and Vines 2014). However, Germany's war debts were never completely paid (GalofréVilà et al. 2019). German war debts were postponed in the Hoover moratorium of 1931 or temporarily suspended in the Lausanne Conference a year later. ${ }^{1}$

Fiscal austerity might simply have been a driver of economic collapse if multipliers were large enough, but Ritschl (2013) reports that these were small. If austerity mattered, it must have been something about the unique way Germany experienced it. Even if austerity did not have a contractionary effect on aggregate demand, it still might have had distributional consequences that, in turn, affected how people voted. Austerity not only hurt the lower middle classes and elites, by increasing tax rates on profits and income, but ostensibly also had a major impact on people's welfare by cutting key social spending lines after 1929. Brüning was commonly known as the "Hunger Chancellor," stressing how these budget cuts threatened living conditions. There is, in fact, some qualitative consensus on Brüning's devastating legacy. Feinstein, Temin, and Toniolo (2008, p. 90) opine that "Brüning introduced a succession of austerity decrees. The descent was cumulative and catastrophic." Several authors also noted that austerity could have contributed to political extremism. For instance, Feldman (2005, p. 494) comments that "Brüning's reliance on emergency decrees had paved the way for a right-wing rule" and Eichengreen (2015, p. 139) that "Brüning's unrelenting austerity, by plunging the economy deeper into recession, increased political polarization."

Hitler also viewed austerity as a springboard to power. Twelve days after Brüning enacted his fourth and last emergency decree, Hitler issued a mass pamphlet titled The Great Illusion of the Last Emergency Decree. He concluded the letter saying that "Although that was not the intention, this emergency decree will help my party to victory, and therefore put an end to the illusions of the present system." There are also attacks on Brüning's cabinet on earlier fiscal plans. For instance, in October 1931, Hitler wrote an Open Letter from Adolf Hitler to the Reich Chancellor in

\footnotetext{
${ }^{1}$ Other explanations invoke the Weimar Republic's electoral system, where each party was allotted a number of seats in the Reichstag proportional to the votes received, which cleared the path for small parties to enter the Reichstag (Jepsen 1953). Historians also stress the animosity between the two major parties of the left and difficulties in building lasting coalitions. However, Evans (2003) notes that proportional representation did not, in fact, encourage the rise of the extreme right and alternative electoral systems might have given the Nazi Party even more seats.
} 
which he asked, "Where has the hereby-reduced number of unemployed been left? Where are the successes of the 'rescue of agriculture'? And when, Mister Chancellor Brüning, did the then-promised reduction of taxes finally begin?"

These pamphlets also made promises to relax the budget constraint if the Nazis were elected. For instance, on May 1932, a pamphlet titled Emergency Economic Program of the NSDAP offered "fundamental improvements in agriculture in general, multiple years of taxation exemption for the settlers, cheap loans and the creation of markets by improving transportation routes, and making them less expensive." On the welfare system, "National Socialism will do all it can to maintain the social insurance system, which has been driven to collapse by the present System." ${ }^{2}$

\section{AUSTERITY AND THE GERMAN ELECTIONS}

In March 1930, Brüning was appointed as German Chancellor by President von Hindenburg and fiscal reforms were quickly implemented, with a first austerity plan in July 1930. Austerity was implemented by emergency decree under Article 48 of the constitution, with the Reichstag eventually consenting without formal debate. From its beginning, austerity was highly unpopular, leading von Hindenburg to dissolve the Reichstag and call new elections. ${ }^{3}$

In the elections of September 1930, the Social Democratic Party (SPD), the political home of the worker movement, remained as the largest party in the Reichstag (yet, moving from 29.8 percent of the total votes in May 1928 to 24.5 percent in 1930). The Center Party, which was Brüning's party, also started to lose popularity (moving from 12.1 to 11.8 percent), and the Communist Party, the main party of protest for those workers disenchanted by the Weimar regime, somewhat managed to collect new votes (moving from 10.6 to 13.1 percent). The German National People's Party (DNVP), a bourgeois, xenophobic far-right party that shared many of the Nazi's extremist views, declined from 14.2 percent of total votes to 7 percent. Above all these changes, support of the Nazi Party surged from almost no support to more than 6 million voters (moving from less than 3 percent to 18.3 percent).

\footnotetext{
${ }^{2}$ There is also evidence that austerity formed part of Goebbels' propaganda machine. For instance, in a speech on 2 May 1931 at the Reichstag, Goebbels very prominently also alluded to tax pressure on the middle class (Goebbels 1931). We thank Hans-Joachim Voth for calling this speech to our attention.

${ }^{3}$ Eichengreen (2018, p. 86) notes, "that the most dramatic cuts were imposed by decree, circumventing normal legislative deliberation, did not foster popular admiration of the politicians then in office or enhance the legitimacy of the constitutional system."
} 
Although austerity was only implemented some months in advance, the September 1930 election was a key turning point in German history because it was seen as a withering verdict against austerity - a message that went unheeded. As discussed by Temin (1990, p. 82), “...it is clear that the vote of 1930 was a resounding rejection of Brüning's policies at an early stage." Initially, only the Nazis (and, to some extent, the Communists) campaigned against austerity, with the DNVP struggling to find a coherent response on the austerity front. For instance, Fulda (2009, p. 158) noted that for the first emergency decree, "the parliamentary DNVP was split: while Hugenberg's followers voted against it, the group around Westarp decided to support it." He also comments that when "the tension between the pro-Brüning DNVP parliamentarians around Westarp and Hugenberg's supporters increased... Goebbels noted in his diary that the DNVP was "finished': "All grist to our mill." "As for the SPD, Brüning's memoirs highlight that he often turned to members of the SPD for support. Successive emergency decrees in June 1931, October 1931, and December 1931 raised nearly all of the main taxes controlled by the Reich (income, wage, turnover, excise duties, tariffs), put limits on spending, introduced exclusions from unemployment and relief benefits, and mandated civil service pay cuts (over 50 percent of the state-level spending bill according to Balderston (1993)).

By the end of May 1932, Brüning was removed from the Chancellorship and was replaced by von Papen. The elections of July 1932 boosted Nazi popularity even more, achieving 37.3 percent of the votes. Yet, the Nazis lacked an overall majority at the Reichstag and von Papen continued as Chancellor. In the second half of 1932, von Papen signaled the end of austerity and started to introduce some stimulus packages, involving employment programs, tax credits, and subsidies for new employment and public works projects (Evans 2003; Feinstein, Temin, and Toniolo 2008). Despite the fact that any short-lived effect was modest in magnitude compared to the cumulative effect of Brüning's austerity, the easing of austerity, along with the ostensible cancellation of war debts at the Lausanne conference and an improved economic environment, ${ }^{5}$ coincided with a decline in Nazi vote share in the elections of November 1932 (collecting 33.1 percent of the votes). As O'Rourke (2010) comments, "by this stage Brüning was gone, his successor adopted some modestly

\footnotetext{
${ }^{4}$ By July 1930, the DNVP was split in two parties, with Westarp's followers founding the Konservative Volkspartei (supporting Brüning's government) and the rest, commanded by Hugenberg, radicalized and tried to approach the Nazi Party.

${ }^{5}$ Between 1932 and 1933, real GDP grew by 6 percent. By comparison, real GDP fell by 8 percent between 1931 and 1932 .
} 
stimulative policies, and there were signs of a partial recovery. Not coincidentally, in November 1932 the Nazi share dipped to 33.1 percent; but by then it was too late, and the Weimar Republic was doomed."

Von Papen had virtually no support in the Reichstag, and in an ill-fated attempt to increase his support, he called for new elections in November of 1932. Yet, given mass discontent and social instabilities, later on, Hindenburg appointed Schleicher of the DNVP as Chancellor. ${ }^{6} \mathrm{He}$ lasted for less than two months. Adolf Hitler was appointed chancellor on 30 January ahead of the decisive elections of March 1933, where the Nazi Party became the largest party (with 44 percent of the votes) and built a bare working majority with the DNVP that offered 8 percent of the votes. $^{7}$ These were the last elections of the Weimar Republic and were tarnished by violence and intimidation and might not be regarded as free and democratic.

Under Brüning's mandate, there was a process of centralizing fiscal policy and the national government began to limit the ability of states to raise tax rates as well limited fiscal transfers to states and localities (Balderston 1993). ${ }^{8}$ James (1986, p. 76) also commented that regional governments were "left with odious taxes and falling revenues." Although austerity was determined at the Reich level, the extent to which it mattered varied regionally. This variation depended on how lower levels of government allocated their revenue to different types of expenditure and what the sources of their tax revenues were. Around 40 percent of the spending cuts were implemented by local authorities, mainly municipalities and the so-called administrative divisions (Regierungsbezirke); 22 percent by the different states; and around one-third by the Reich (Newcomer 1936). Hence, the impact of Reich mandated cuts on the states varied according to a number of predetermined fixed factors, including population and land area, number of schools, highway mileage, and the distribution of income (Newcomer 1936, p. 205). ${ }^{9}$

\footnotetext{
${ }^{6}$ Schleicher also introduced some public works programs.

${ }^{7}$ In the election of 1933, the DNVP presented in the elections as part of a coalition the Kampffront Schwarz-Weiß-Rot, which was an electoral alliance of three parties: the DNVP, the Stahlhelm, and Landbund.

${ }^{8}$ There were two main bases for collection and redistributing revenue: origin and population. While the origin base (returning revenue to the locality where it was collected) failed to take into account the local need factor, redistribution by the population principle could be effective in terms of "need." Yet, the extent of redistribution depended on state political bargains and most of the taxes in question were distributed on an origin basis (Wueller 1933, p. 38).

${ }^{9}$ It is possible that greater unemployment also generated greater transfers via the unemployment insurance scheme. Yet, by 1931, the period of eligibility for unemployment relief was drastically restricted and nearly all people under 21 years were excluded from welfare benefits. These measures were offset by the end of 1931 somewhat with greater relief payments and a partial rollback of the exclusion (Balderston 1993).
} 
Political affinity to Brüning's policies might have mattered, but in essence, spending cuts were mandated at the central level. The room to maneuver in the states was also highly constrained. States could no longer borrow on international capital markets after 1930, and only a small share of state spending was accounted for by local tax revenue over which a state had control. While local politicians could potentially shift spending between categories, the Reich increasingly dictated the way in which states should spend money; put caps on spending categories; and, in many instances, relied heavily on targeted Reich subsidies or transfers. Thus, states were also constrained both by an inability to legislate tax rates and by the traditional ways of redistributing tax revenue. Our bottom line is that responding to the recession with discretionary spending was not much of a possibility and both income tax ${ }^{10}$ and expenditure were largely out of the hands of state governments and local authorities. ${ }^{11}$

\section{DATA}

We collected data from official German sources (see our Online Data Appendix for details and Galofré-Vilà et al. (2020)). Our analysis begins by measuring the impact of austerity on electoral outcomes at the city level. Data on electoral returns for the Reichstag elections are from the official publication Statistik des Deutschen Reiches (volumes Wahlem zum Reichstag), with all the other data at the city level coming from the Statistisches Jahrbuch Deutscher Städte, which report data for cities above 50,000 inhabitants ( $N$ $=98$ ). For each city, we collected city spending data for each fiscal year from 1929/30 to 1932/33, which includes transfers from higher levels of government and spending by budget category, in 1,000 RM. Such detailed data at the city level allow us to look at the type of spending and the potential mechanisms by which spending changes can affect electoral outcomes. The fiscal years ran from 1 April to 31 March, and when we say 1929, this refers to the fiscal year 1929/30. We also collected data from the federal transfers to cities (a variable called Überweisungen aus Reichsteuern) to construct a Bartik-style instrument, as discussed subsequently.

To test competing explanations, we further used data on city-level unemployment. Unemployment is defined as the number of people in the labor force not working and registered in the local offices as unemployed. We proxy city economic conditions by the construction of new residential

\footnotetext{
${ }^{10}$ Income tax was a key tax in the Weimar revenue system (with 20 percent of total revenue).

${ }^{11}$ Here, Newcomer (1936, p. 205) comments that "it is unfortunate that the equalizing factors adopted have been vitiated in a number of instances by guarantees of pre-war income." See also Wueller (1933, p. 36).
} 
apartment buildings. We also collected mortality data from the bulletins of the Reichs-Gesundheitsblatt. These bulletins report detailed mortality data at the weekly level for cities with a population larger than 100,000 inhabitants $(N=51)$.

We also study district- (kreis-) level data $(N=1,024)$, where data on taxes, but not spending, are available. Electoral and fiscal data on taxes are from the official Statistik des Deutschen Reiches. For taxes, we collected data on the number of taxpayers, total taxable income, and total revenue for each state (in 1,000 RM) on two main federally administered income taxes: the lohnsteuer, a withholding tax deducted at the source, and the einkommenssteuer, an ex-post income declaration tax only paid by middle and high rate payers. For the "wage tax" (lohnsteuer), data are available in 1928/29 and 1932/33, and for the "income tax" (einkommenssteuer) for the years 1928/29, 1929/30, and 1932/33 (Dell 2007). Despite missing data for some years, the available years allow us to capture the main changes in taxation in the period of interest (September 1930-March 1933), and rather than having highly temporally disaggregated data, we rely on benchmark years under the assumption that the impact of austerity is cumulative. We also collected state-level data on taxes (the lohnsteuer and einkommenssteuer) for the same years as in the district sample. ${ }^{12}$

From the statistical abstracts Statistisches Jahrbuch für das Deutsche Reich, we collected state-level data on spending, unemployment (number of people in the labor force not working), an index of hourly wages, ${ }^{13}$ and a proxy economic output (generation of electricity, in 1,000 kWh). For the latter one, we use a proxy based on electricity generation, as these two correlate closely, since the vast majority of goods and services are produced using electricity. Other district-level data used in the Online Data Appendix, such as the number of welfare recipients, are from Statistik des Deutschen Reiches (volume Die Öffentliche Fürsorge im Deutschen Reich). Table A1 reports the main summary statistics on key variables.

On the magnitude of austerity, as Figure 1 shows, between 1930 and 1932, state-level real expenditure was cut by 8 percent (nominal total spending fell by about 25 percent) and Reich level real expenditure fell by 14 percent (30 percent nominal). ${ }^{14}$ These were not insignificant components of aggregate demand since, together, state and Reich expenditure totaled close to 30 percent of GDP in 1928/29.

\footnotetext{
${ }^{12}$ For simplicity, when we say states, we also mean Prussian provinces.

${ }^{13}$ We created a state-level index of nominal wages averaging the monthly data from the hourly wages paid in four occupations (construction, wood, and skilled and unskilled workers in metallurgy) in 38 large cities that are located within each of the states.

14 The spending data include transfers to other public authorities.
} 


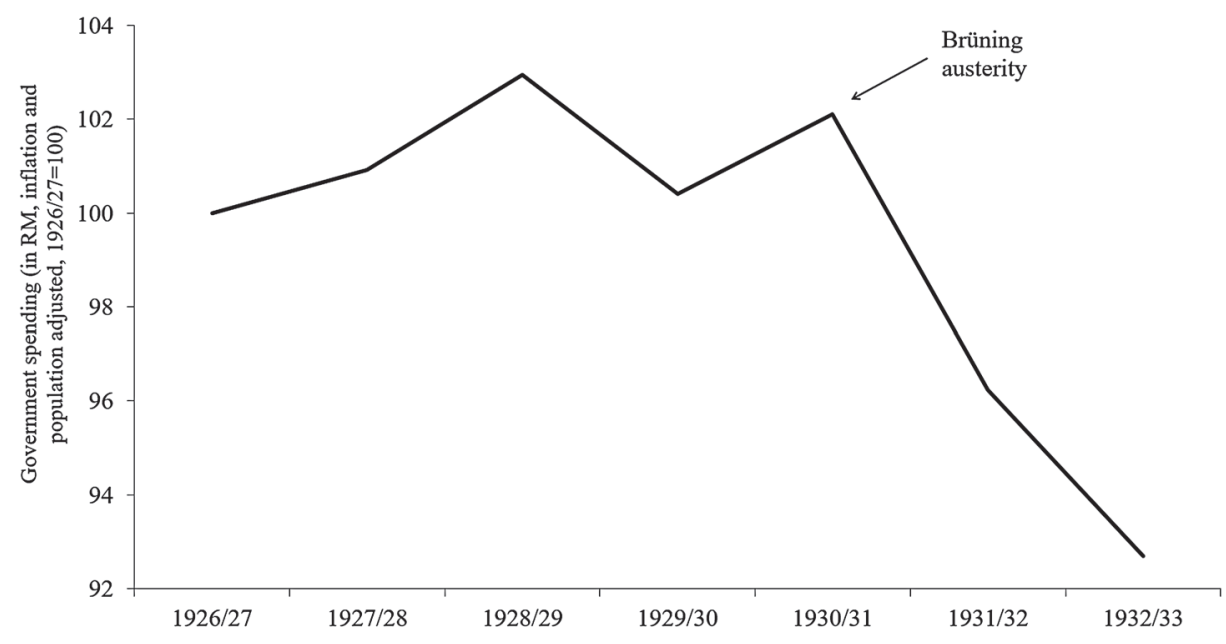

FIGURE 1

DEVELOPMENT OF REAL PER CAPITA STATE SPENDING IN GERMANY, $1926 / 27-1932 / 33(1926 / 27=100)$

Notes: This figure shows the evolution of real per capita government spending between 1926/27 and 1932/33. Nominal state-level expenditure is as reported in James (1986) following fiscal years and accounting for transfers to other public authorities. Data were originally collected from Official Statistics (Statistiches Jahrbuch für das Deutsche Reich). Nominal expenditure has been adjusted for inflation using the price index $(1913 / 14=100)$ from Jürgen Sensch in HISTATDatenkompilation online (Preisindizes für die Lebenshaltung in Deutschland 1924 bis 2001) and for population using the data from Piketty and Zucman (Data Appendix for Capital is Back, Table DE1).

Source: See the text.

\section{NAZI SUPPORT AND CITY-LEVEL SPENDING}

With the launch of austerity in July 1930, the number of votes for the Nazi Party soared from 6 to 14 million between the elections of September 1930 and July 1932. Indeed, as Figure 2 suggests, there is a close negative association between the increase in the Nazi vote share between September 1930 and July 1932 and the change in city-level spending between 1929/30 and 1930/31. We next explore these issues more rigorously and implement some empirical strategies to limit biases due to endogeneity.

\section{Results}

We begin our analysis reporting the results of statistical models where the dependent variable is the level of the Nazi vote share across cities in federal elections. We use city fixed effects throughout so that we rely 

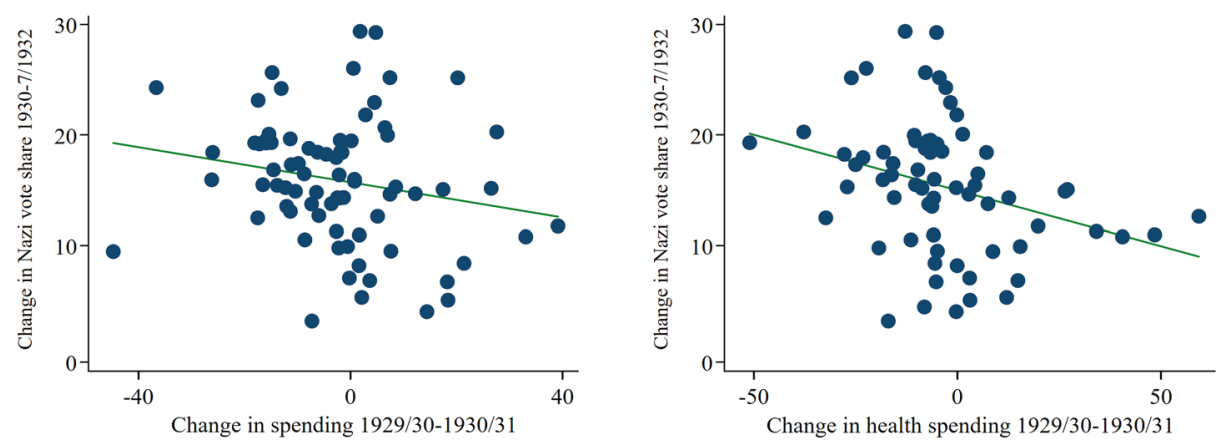

FIGURE 2

CHANGES IN VOTE FOR THE NAZI PARTY AND CITY-LEVEL SPENDING,

$1930-1932$

Notes: Data on the $y$-axis are the difference in the vote share going to the Nazi Party between the elections of September 1930 and July 1932. The $x$-axis shows the change in total city-level government spending in percentage points (left figure) and the change in health and well-being city-level government spending (right figure) in percentage points. The $p$-value in the right figure is equal to $0.040(r=-0.249)$ and in the left figure is equal to $0.009(r=-0.320)$.

Source: See the text.

on within-city variation to identify the impact of austerity on Nazi vote share. With these specifications, our models yield a difference-in-differences with an intensity of treatment interpretation based on

$$
\begin{gathered}
N A Z I_{c t}=\alpha+\beta_{1} \ln \left(\text { Expenditures }_{c t}\right)+\beta_{2} \ln \left(\text { Unemployment }_{c t}\right) \\
+\beta_{3} \ln \left(\text { Output }_{c t}\right)+\mu_{c}+\delta_{t}+e_{c t},
\end{gathered}
$$

where $c$ is a city, $t$ indexes elections, and NAZI denotes the vote share of the Nazi Party as measured by the ratio of the number of votes to the Nazi Party over the total number of (valid) votes cast. Expenditures comprises all categories of city expenditure, Unemployment $t_{c t}$ is the number of registered unemployed in a city, Output ${ }_{c t}$ is our proxy for economic output in a city, and $e_{c t}$ is an error term. These control variables are expressed in natural logarithms. ${ }^{15} \mathrm{We}$ standardize data to have a mean of zero and a standard deviation of one so coefficients across models are directly comparable. We also include city fixed effects $\left(\mu_{c}\right)$ and fixed effects for the calendar years of 1932 and $1933\left(\delta_{t}\right)$. We report standard errors clustered at the administrative division level. There are 44 clusters, and by clustering at the administrative division (above the city level), we

\footnotetext{
${ }^{15}$ We use the values of city-level government spending for fiscal year 1929/30 for the election of September 1930, values for 1931/32 for the elections of July and November 1932, and values of $1932 / 33$ for the election of 1933 .
} 
TABLE 1

IMPACT OF CITY EXPENDITURES ON THE NAZI PARTY VOTE SHARE, ALL NATIONAL ELECTIONS 1930-1933

\begin{tabular}{lcccc}
\hline \hline & $(1)$ & $(2)$ & $(3)$ & $(4)$ \\
\hline ln Expenditures & $-0.345^{* *}$ & $-0.415^{* * *}$ & $-0.351^{* *}$ & $-0.353^{* *}$ \\
& $(0.130)$ & $(0.133)$ & $(0.169)$ & $(0.155)$ \\
ln Unemployment & & 0.573 & 0.259 & $0.555^{* * *}$ \\
& & $(0.361)$ & $(0.183)$ & $(0.139)$ \\
$\ln$ Economic output & & 0.033 & 0.033 & $-0.255^{* *}$ \\
& & $(0.044)$ & $(0.154)$ & $(0.122)$ \\
\hline Number of observations & 260 & 260 & 260 & 260 \\
\hline City-level fixed effect & Yes & Yes & Yes & Yes \\
Fixed effect 1932 & Yes & Yes & No & No \\
Fixed effect 1933 & Yes & Yes & No & No \\
State $\times$ period fixed effects & No & No & Yes & No \\
Admin. division $\times$ period fixed effects & No & No & No & Yes \\
\hline
\end{tabular}

Notes: Dependent variable is the percentage share $(\times 100)$ of the valid votes cast going to the Nazi Party in the different elections. Equation (1) is equivalent to the results we show in Column (2). We use the controls of 1929 for the election of September 1930, 1931 for the elections of July and November 1932, and 1932 for the election of March 1933. We estimate the linear models with many levels of fixed effects, as in Correia (2017). We balance the sample for singleton groups and use a balanced panel with robust standard errors (in parentheses) clustered on 44 administrative divisions. We standardize all variables with a mean of zero and a standard deviation of one. ${ }^{* * *} p$ $<0.01,{ }^{* *} p<0.05, * p<0.1$.

Source: See the text.

allow for arbitrary spatial correlations of the error term within the cluster. Additionally, many of the variables were decided above the city level and fixed effects already pick up potential spatial correlations.

In Table 1 (Column (2)), we show that a one-standard-deviation increase in the natural logarithm of spending is associated with a decrease in Nazi vote share (in standard deviation terms) of -0.42 ( 95 percent confidence interval (CI): from -0.68 to -0.15 ). This specification, which pools data for the four elections between 1930 and 1933, is robust to the inclusion of administrative division or state by period fixed effects (Columns (3) and (4)). ${ }^{16}$ These last specifications control for time-varying unobservable shocks or arbitrary unobserved trends at the administrative division or state level. Since shocks are likely to be highly spatially correlated, these controls mop up the effect of spending changes after controlling for local economic and political shocks.

\footnotetext{
${ }^{16}$ Specifically, we interact state and administrative division level fixed effects with an indicator for each year 1932 and 1933.
} 
This table also displays the results for other competing explanations for the rise of the Nazi Party. Despite the fact that the coefficient on unemployment at the city-level displays a positive sign, it is only statistically significant in Column (4). As Ferguson (1997, p. 267) notes, this is a likely outcome, as "it is a popular misconception that because high unemployment coincided with rising Nazi support, the unemployed must have voted for Hitler. Although some did, unemployed workers were more likely to turn to Communism than to Nazism." When controlling for austerity and unemployment, in most cases, the economic output variable is also not statistically significant.

Since we can differentiate party votes in the data, we next modify the outcome variable to be the vote share among other parties. This change allows us to see how austerity affected the rest of the German political spectrum. To also show that our results are not driven by a single election (or group of elections), we provide the results in three separate forest plots, pooling data for the elections of 1930 and 1933; elections of 1930 and 1932 (both elections); and the four elections between 1930 and 1933.

Results for the Nazi Party in Figure 3 show that there is a negative and statistically significant association between spending and the Nazi Party vote share in the different elections between 1930 and 1933. Results for the other parties suggest that austerity mostly drew votes from the Center Party. This is not surprising as the Center Party was Brüning's party and the party became very unpopular for consolidating the budget. For instance, Straumann $(2019$, p. 207) comments that "the harsh austerity measures of December 1931 ... pushed the popularity of the Brüning cabinet down to a new low." Results also display a positive sign for the SPD (although not always statistically significant) and the Communist Party (when avoiding the violent election of 1933). Results for the DNVP highlight its lack of a political position on the austerity front.

\section{Robustness Checks}

In Table A2, we also pool all elections and study the dynamics of the effects via interaction terms. Specifically, we interacted the spending data with a dummy for each election. Therefore, we estimated three coefficients, 7/1932, 11/1932, and 1/1933, and then one for austerity uninteracted, which corresponds to the "omitted" category, which is 1930. In this way, we show that the austerity effect is stable across time, as the sample is kept stable and the reference point still remains 1930. 

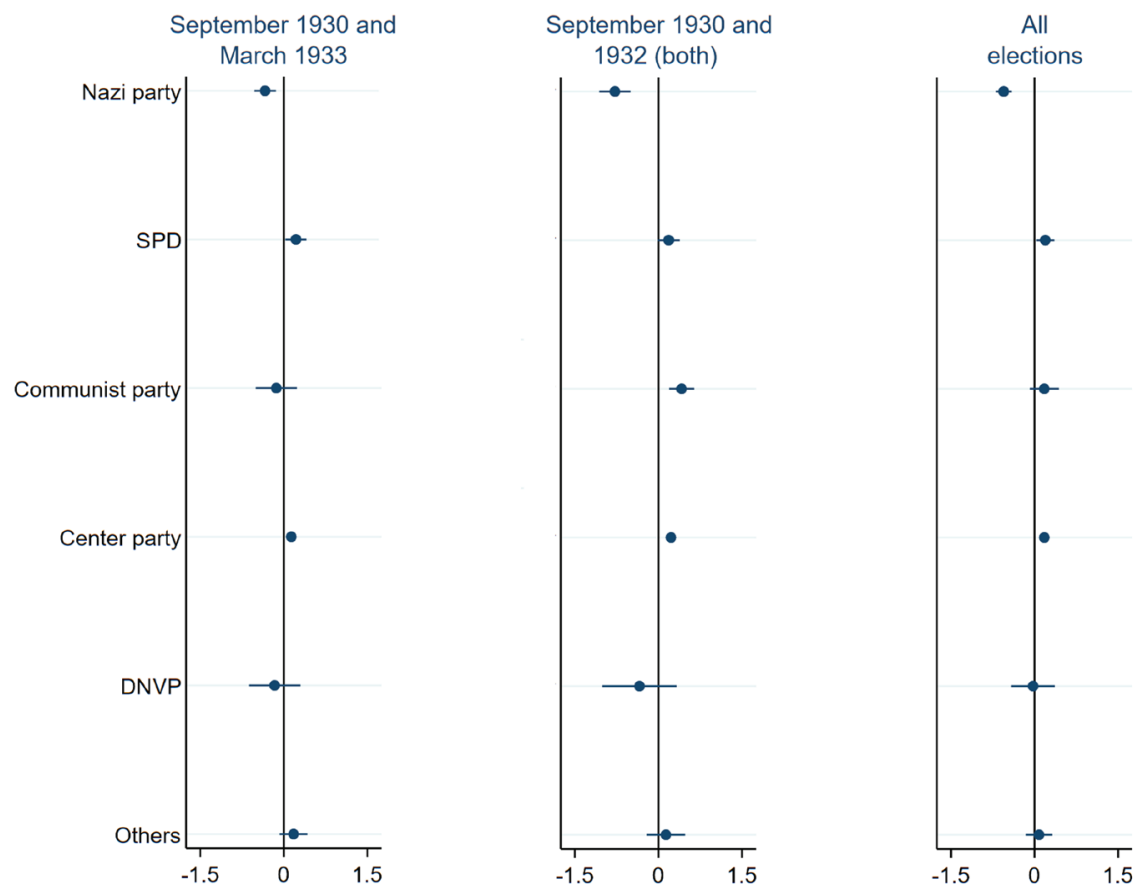

FIGURE 3

IMPACT OF CITY EXPENDITURES ON THE NAZI PARTY VOTE SHARE, ELECTIONS 1930, 1932, AND 1933

Notes: Dependent variable is the percentage share $(\times 100)$ of the valid votes cast going to the main parties in the different elections. Models are estimated independently and adjusted for unemployment and economic output. We use the controls of 1929 for the election of September 1930, 1931 for the elections of July and November 1932, and 1932 for the election of March 1933. We use a balanced panel with robust standard errors clustered on 44 administrative divisions. SPD stands for the Social Democratic Party and DNVP for the German National People's Party. In the election of 1933, the DNVP presented in the election as part of the Kampffront Schwarz-Weiß-Rot, which was an electoral alliance of three parties: the DNVP, the Stahlhelm, and Landbund. All models include city-level fixed effects, and the forest plot with the elections 1930 and 1932 (both) includes a fixed effect for 1931/32 and "all elections" fixed effects for 1932 and 1933. We standardized all variables with a mean of zero and a standard deviation of one. Source: See the text.

We further test for the validity of our estimates in different ways. ${ }^{17}$ For instance, in Table A3, we divide each of the right-hand-side variables by population to show that our fixed effects models are very likely to proxy for a stable population over the short horizon between 1930 and 1933.

${ }^{17}$ We also used the data on the number of entries to the Nazi Party at the city level from Satyanath, Voigtländer, and Voth (2017) and explored the impact of austerity on joining the Nazi Party. Specifically, we looked at the log of the number of entries in the Nazi Party in the preceding year and focused on the inflow of people into the party rather than on the stock of party members. Using a specification equivalent to Equation (1) and pooling data from 1931 to 1933, the results strengthen the case that nationalist and racist ideals became more salient when compounded by austerity, driving people toward the Nazi ideology (Shirer 1960). 
Table A4 further explores the interaction of the shock of the Depression with social structure. We interacted year fixed effects with the share of blue-collar workers in 1925 and the share of the population identifying as Catholic or Protestant. ${ }^{18}$ The time interactions on religious identity are significant, suggesting a role for such interaction. However, austerity mattered in a similar way in Catholic and Protestant areas, though the impact is higher in places with a Jewish community. ${ }^{19}$

\section{Instrumental Variable and Endogeneity}

One may worry that changes in spending were choice variables reflecting the (unobservable) state of the underlying economy or the level of local political competition. Politicians could alter spending levels in response to these and their perceptions of these and other variables, making it problematic to infer the impact of exogenous changes in spending on votes for an extreme party such as the Nazis. To deal with the potential endogeneity of expenditures, we employ a shift share instrumental variable in the spirit of Aizer (2010), which relies on variation at the national level in "across-the-board" cuts imposed by Brüning. Consider the following stylized equation for total government spending $G$ in city $c$ in fiscal year $t$ :

$$
G_{c t}=G_{F c t}+G_{L c t}
$$

Spending in city $c$ is composed of two components. One is federal transfers or the federally mandated level of spending $G_{F c t}$. This variable could also be construed as local spending based on local claims to federal revenue streams, where the subscript $F$ denotes federal transfers or mandates to city $c$. The other component, $G_{L c t}$ is based on local decision-making and local revenues. Assuming that this spending is constant, the change in total spending between period $t$ and period $t-1$ given an $(\alpha-1)$ percent change in federal spending applied to all localities $(0 \leq \alpha \leq 1)$ is given by

$$
\% \Delta G_{c t}=\frac{G_{F c t-1}}{G_{c t-1}} \times(\alpha-1) .
$$

The absolute value of the percentage change in spending is directly related to the share of federal spending in total city spending. That is,

\footnotetext{
${ }^{18}$ Using Equation (1), we also split the sample for Prussian and non-Prussian cities and found that in both cases results are negative and statistically significant, with point estimates being larger in Prussian cities.

${ }^{19}$ In Table A5, we also show that results hold when we control for the severity of the depression using data on the number of welfare recipients. While this variable might be colinear with spending, not controlling for spending but for the number of recipients suggests that expectations might also have mattered. People could also respond to perceived austerity rather than actual exposure to austerity.
} 
the larger the share of $G_{F c t-1}$ in $G_{c t-1}$, the larger the percentage fall in total spending, $\left(\% \Delta G_{c t}\right)$, for a $(\alpha-1) \%$ change in $G_{F c t-1}$. Our instrument, therefore, is the initial share of federal transfers in total city spending in 1929 interacted with year indicators represented by $\delta_{t}$, which themselves proxy for the across-the-board nationally imposed spending cuts. This two-stage least squares (2SLS) approach is reminiscent of Nakamura and Steinsson (2014) or Chodorow-Reich et al. (2012).

To satisfy exogeneity, we assume that $E\left[\left(\frac{G_{F c 1929}}{G_{c 1929}} \cdot \delta_{t}\right) e_{c t}\right]=0$. In a broader survey on shift-share instruments, Goldsmith-Pinkham, Sorkin, and Swift (2020) argue that if initial shares $\left(\frac{G_{F c 1929}}{G_{c 1929}}\right)$ are exogenous, the Bartik-style or shift-share instrument boils down to using initial shares (interacted with time dummies) as excluded instruments. With two sectors, they also show it is only necessary to use one sector share and this is equivalent to a Bartik approach. To satisfy the exclusion restriction, one would have to believe that reliance on the central government in 1929 was not related to the unobservables driving the change in Nazi vote share. As suggested by Goldsmith-Pinkham, Sorkin, and Swift (2020), we tested this by regressing the initial share on observables such as the share of Protestants and Catholics, levels of unemployment, or the construction of new buildings. In none of the cases were these variables statistically significant. For relevance, the log deviation in spending from the within-city mean must be correlated with the initial dependency on the Reich transfers. This would evidently be true unless local spending changes completely offset (orthogonal) Reich spending changes. This is not possible since localities could not fund spending by borrowing due to financial market dislocation and due to the fact that total tax revenue was falling as a result of the decline in aggregate activity.

As Table 2 shows, using ordinary least squares (OLS), the impact in terms of standard deviations in vote share for the Nazi Party associated with a one-standard-deviation increase in the percentage change in spending is -0.78 ( 95 percent CI: from -1.21 to -0.34 ) in the elections of 1930 and 1932 (both) and -0.55 (95 percent CI: from -0.77 to -0.34) when considering all elections. ${ }^{20}$ Results using 2 SLS are just 15 percent larger (in absolute magnitude) than the OLS results in Column

\footnotetext{
${ }^{20}$ We also checked for linearity, categorizing the spending data into bins and including the dummy variables for the bins in the model. We also explored this with bins of different sizes in the spending data. The assumption of linearity is largely suitable.
} 
TABLE 2

IMPACT OF CITY EXPENDITURES ON THE NAZI PARTY VOTE SHARE USING A BARTIK INSTRUMENT, NATIONAL ELECTIONS 1930, 1932, AND 1933

\begin{tabular}{|c|c|c|c|c|}
\hline & \multicolumn{2}{|c|}{ Elections 1930 and 1932 (Both) } & \multicolumn{2}{|c|}{ All Elections } \\
\hline & OLS & 2SLS & OLS & 2SLS \\
\hline & (1) & (2) & (3) & (4) \\
\hline ln Expenditures & $\begin{array}{c}-0.781 * * * \\
(0.215)\end{array}$ & $\begin{array}{c}-0.896 * * \\
(0.444)\end{array}$ & $\begin{array}{c}-0.553 * * * \\
(0.108)\end{array}$ & $\begin{array}{c}-0.683 * * \\
(0.337)\end{array}$ \\
\hline In Unemployment & $\begin{array}{l}1.008^{* *} \\
(0.412)\end{array}$ & $\begin{array}{c}1.012 * * * \\
(0.379)\end{array}$ & $\begin{array}{c}0.654 * * \\
(0.295)\end{array}$ & $\begin{array}{c}0.682 * * * \\
(0.233)\end{array}$ \\
\hline In Economic output & $\begin{array}{l}-0.014 \\
(0.118)\end{array}$ & $\begin{array}{l}-0.009 \\
(0.093)\end{array}$ & $\begin{array}{c}0.020 \\
(0.044)\end{array}$ & $\begin{array}{c}0.019 \\
(0.053)\end{array}$ \\
\hline$F$-test excluded instrument & & 14.16 & & 20.69 \\
\hline Rubin-Anderson test ( $p$-value) & & 0.017 & & 0.042 \\
\hline Number of cities & 231 & 231 & 308 & 308 \\
\hline City-level fixed effect & Yes & Yes & Yes & Yes \\
\hline Fixed effect $1931 / 32$ & Yes & Yes & Yes & Yes \\
\hline Fixed effect 1932/33 & No & No & Yes & Yes \\
\hline
\end{tabular}

Notes: Dependent variable is the percentage share $(\times 100)$ of the valid votes cast going to the main parties in the different elections. We use the controls of 1929 for the election of September 1930, 1931 for the elections of July and November 1932, and 1932 for the election of March 1933. The first-stage coefficient on the initial average income tax rate is negative and highly significant $(-0.103 ; p$-value $=0.000 ; 95$ percent CI: -0.129 to -0.077$)$. We use a balanced panel with standard errors clustered on 44 administrative divisions. For details on the instrument, refer to the text. All models include time and city-level fixed effects. We standardize all variables with a mean of zero and a standard deviation of one. ${ }^{* *} p<0.01,{ }^{* *} p<0.05,{ }^{*} p<0.1$.

Source: See the text.

(4), showing that OLS results may not be highly biased. In Table A6, we also show the Bartik results using models in differences.

\section{Mechanisms}

In Figure 4, we modify Equation (1) and, instead of all city-level expenditure, we study the impact of changes in different types of expenditure. Interestingly, most of the effect of austerity is driven by spending changes in health and well-being ( -1.03 : 95 percent CI: from -1.53 to $-0.52)$ and housing $(-0.21$ : 95 percent $\mathrm{CI}$ : from -0.39 to -0.03$)$. These were among the budgets most affected by austerity. ${ }^{21}$ The size of the effect for spending changes in health and well-being is 32 percent higher than

${ }^{21}$ As noted by Straumann $(2019$, p. 70$)$ on the Second Emergency Decree, "the plan proposed a series of spending cuts, notably of health insurance compensations and of revenues apportioned to states and municipalities." 

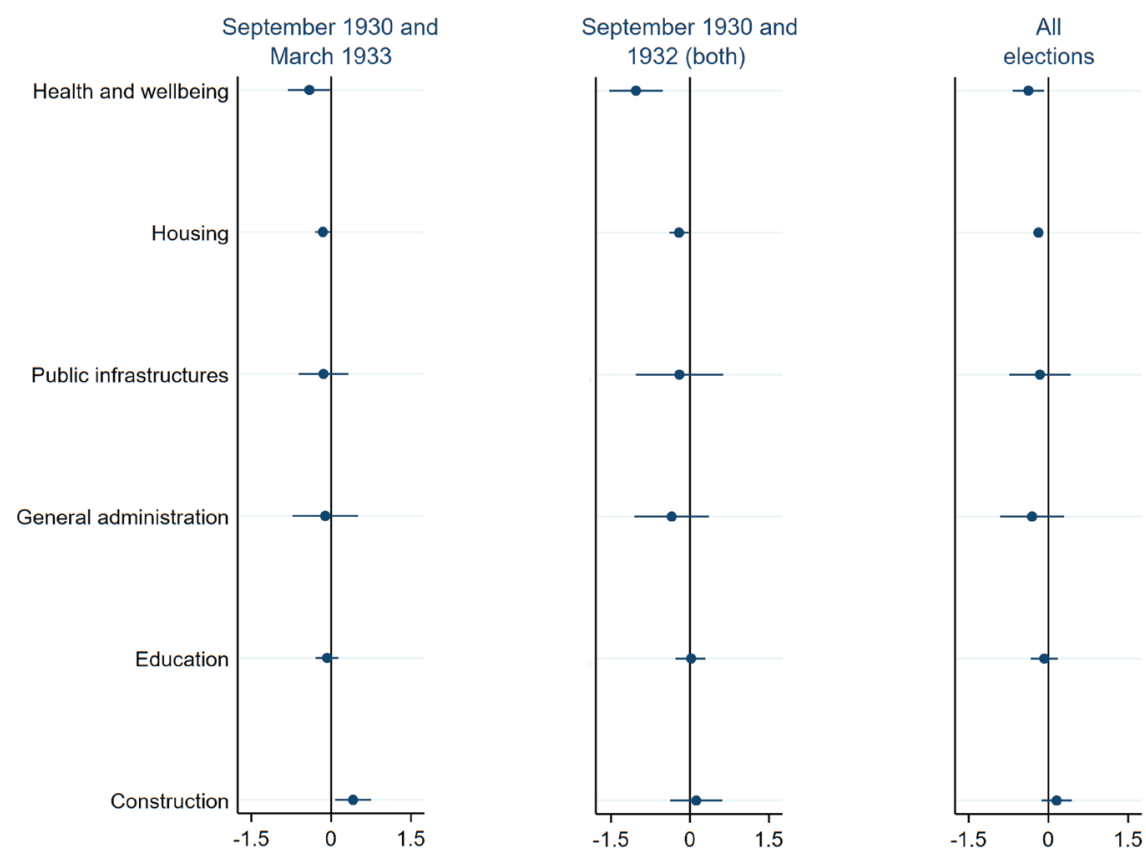

FIGURE 4

IMPACT OF CITY EXPENDITURES BY BUDGET CATEGORY ON THE NAZI PARTY VOTE SHARE, ELECTIONS 1930, 1932, AND 1933

Notes: Dependent variable is the percentage share $(\times 100)$ of the valid votes cast going to the Nazi Party in the different elections. Models are estimated independently and adjusted for unemployment and economic output. We use the controls of 1929 for the election of September 1930, 1931 for the elections of July and November 1932, and 1932 for the elections of March 1933. We use a balanced panel with robust standard errors clustered on 44 administrative divisions. All models include city-level fixed effects, and the forest plot with the elections 1930 and 1932 (both) includes a fixed effect for 1931/32 and "all elections" fixed effects for 1931/32 and 1932/33. We standardized all variables with a mean of zero and a standard deviation of one.

Source: See the text.

the overall effects of the spending changes presented in the previous table, showing that social spending changes plausibly exacerbated the suffering of the German masses. There is also a positive effect of expenditure in construction and the Nazi vote share between the elections of September 1930 and 1933. As we have already seen, by the end of 1932, von Papen and Schleicher introduced some tax discounts as well as construction and work programs, which, along with Hitler's promise to construct an autobahn, were symbols of a new era of economic competence and the end of austerity (Voigtländer and Voth 2019). However, the effect disappears when we introduce data for the austerity years and the elections of 1932.

The literature also stresses that Brüning's fiscal plans were part of a political strategy to elicit international sympathy for German suffering, putting 
an end to WWI reparations..$^{22}$ Coinciding with the fiscal retrenchment, mortality rates, which had been declining, started to rise rapidly after 1932. One mechanism for the rise of populist parties is that they gain the most votes where health fares worst. This link was outlined by some commentators at the time. For instance, by the fall of October 1930, Hjalmar Schacht (former head of the Reichsbank) gave an interview to the American press saying that, "If the German people are going to starve, there are going to be many more Hitlers" (The New York Times, 3 October 1930).

Next, we report suggestive evidence that the effect of spending cuts was through the channel of higher mortality. In Table 3, we use Equation (1) and also add a control for mortality. Since we use city fixed effects, mortality here can be interpreted as excess mortality, that is, within-city changes or deviations of mortality from its within-sample mean. Instead of overall spending, we use only spending in health and well-being. Column (1) shows that after controlling for unemployment and economic output and other fixed effects, increases in spending are negatively and statistically related to Nazi Party vote. Similarly, Column (2) shows that without controlling for spending, higher mortality is associated with higher Nazi vote share. However, once we add the mortality control (Column (3)), expenditure is no longer statistically significant and the size of the coefficient declines by 34 percent. If we remove the deaths from cancers and a category for ill-defined causes, the coefficient for mortality remains statistically significant at the 1 percent level of confidence (Column (5)), but the coefficient on spending declines by more than half and is not statistically significant. Although results are weaker for infant mortality, possibly because births to the poorest families fall disproportionately during a recession (Dehejia and Lleras-Muney 2004), they display a low $p$-value (Column (7)). This result further illustrates that the impact of austerity was potentially channeled through suffering (as measured by changes in mortality). It is also interesting that the coefficients on unemployment and economic output, once we control for austerity, are similar before and after we include the mortality control.

\section{NAZI SUPPORT AND DISTRICT-LEVEL TAXES}

\section{Results}

We next move to district-level data. Since spending data at the district level are unavailable from national sources, we rely on within-district

\footnotetext{
${ }^{22}$ This strategy was never a clear political winner and soon lacked an economic rationale. By June 1931, the Hoover Moratorium had suspended Germany's WWI debts for one year. A year later, in July 1932, reparations were permanently postponed at the Lausanne Conference.
} 
102 Galofré-Vilà, Meissner, McKee, and Stuckler

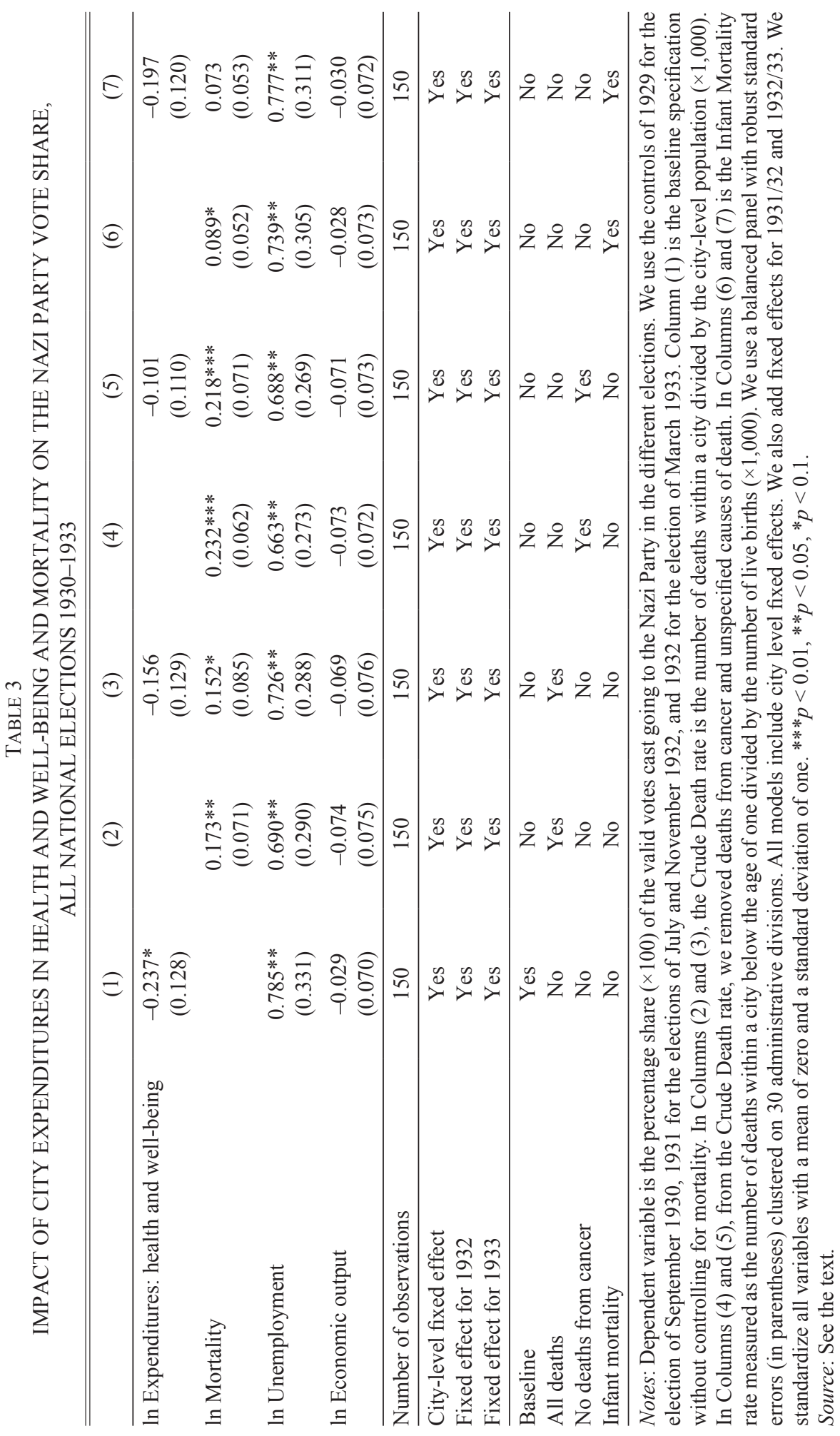


variation in income taxes as our measure of austerity. We assume that for an individual voter, changes in taxes have an impact analogous, if not proportional, to cuts in spending. Both fiscal variables would presumably have an economic and potentially psychic impact on the well-being and political preferences of an individual voter. Changes in tax rates would alter an agent's budget constraint and choices much the same as a direct change in income due to modifications of targeted transfers or other government spending on services. Alternatively, utility derived from public good flows could also be altered to the extent that public goods are a function of spending or the revenue that is necessary to finance such spending.

We model the impact of austerity on Nazi vote share using the following equation:

$$
\begin{gathered}
N A Z I_{d t}=\beta_{1} \ln (\text { Tax Rate }(a))_{d t}+\beta_{2} \ln \left(\text { Wages }_{s t}\right) \\
+\beta_{3} \ln \left(\text { Unemployment }_{s t}\right)+\beta_{4} \ln \left(\text { Output }_{s t}\right)+\mu_{d}+\delta_{t}+e_{d t},
\end{gathered}
$$

where the average Tax Rate (either the average rate of income or wage taxes and denoted by $a$ ) is calculated as the ratio of tax revenue divided by total declared taxable income. Tax rates are indexed by districts $d$, other controls by states $s$, and $t$ is an election period (September 1930, July 1932, November 1932, or March 1933). Since we do not have annual data on taxes, we linked the income taxes for the fiscal year 1929/30 to the elections of September 1930 and the taxes for the fiscal year 1932/33 to the elections of 1932 and 1933. Since wage taxes are unavailable for the fiscal year 1929/30, we had to link the wage taxes for 1928/29 to the elections of 1930 and the taxes for 1932/33 to the elections of 1932 and 1933. NAZI denotes the percentage point vote share of the Nazi Party in the different federal elections. We also include district fixed effects $\left(\mu_{d}\right)$ and a fixed effect for the fiscal year 1932/33 $\left(\delta_{t}\right)$ and report standard errors clustered at the district and state levels.

The results in Table 4 (Column (1)) show that the impact in terms of standard deviations in vote share for the Nazi Party associated with a one-standard-deviation rise in the natural logarithm of the average tax rate is 0.16 using income taxes (95 percent CI: from 0.78 to 0.25 ) and 0.19 using wage taxes (95 percent CI: from 0.09 to 0.30 ). This result suggests that the Nazi Party received more votes in districts with greater austerity when austerity is measured as rises in the tax rate.

To control for endogeneity, we also instrumented the tax rate with the level of the average income tax rate in 1928 (Column (7)) interacted with time dummies. The percentage change in the average income tax rate $T$ 
104 Galofré-Vilà, Meissner, McKee, and Stuckler

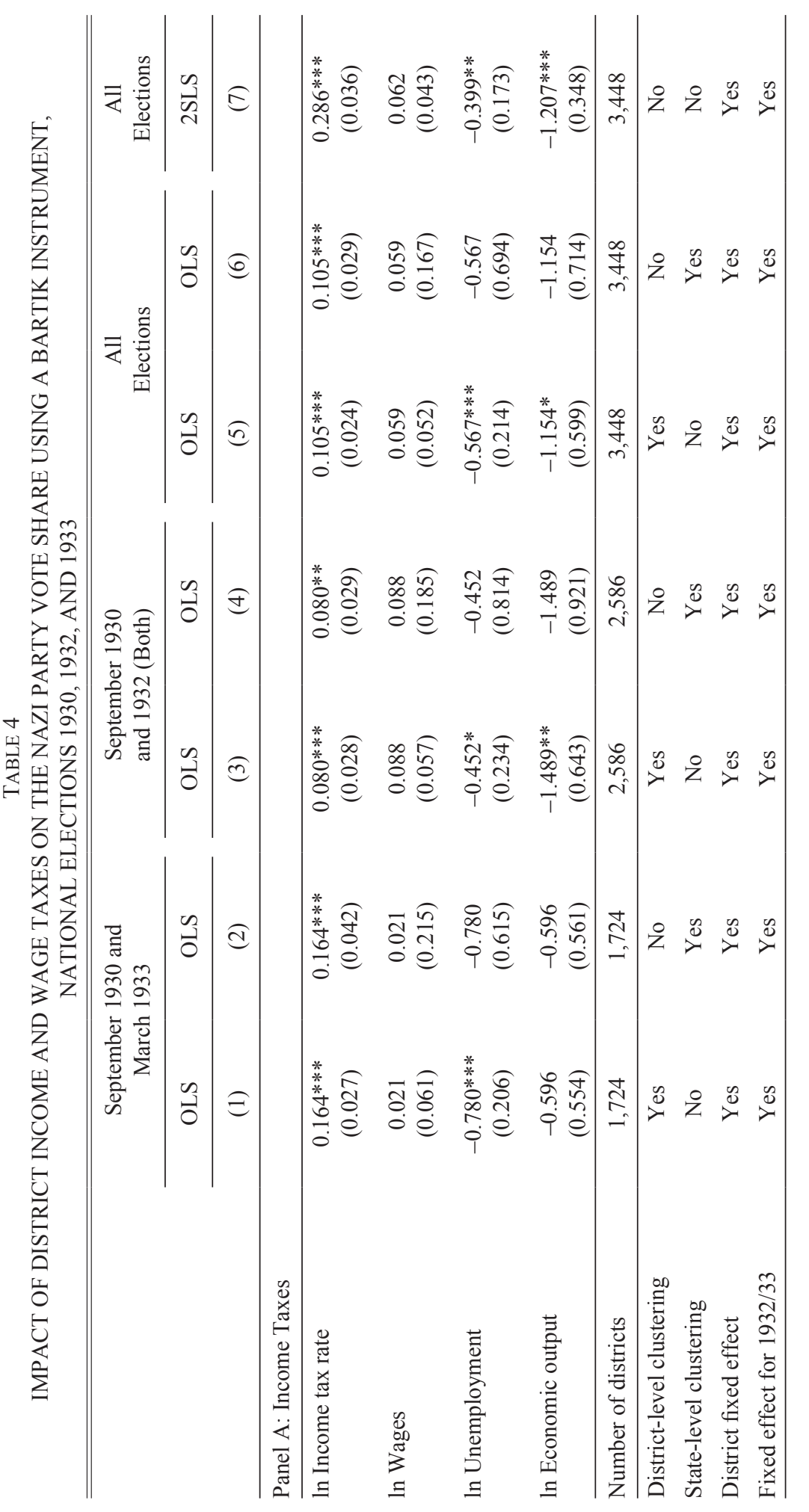




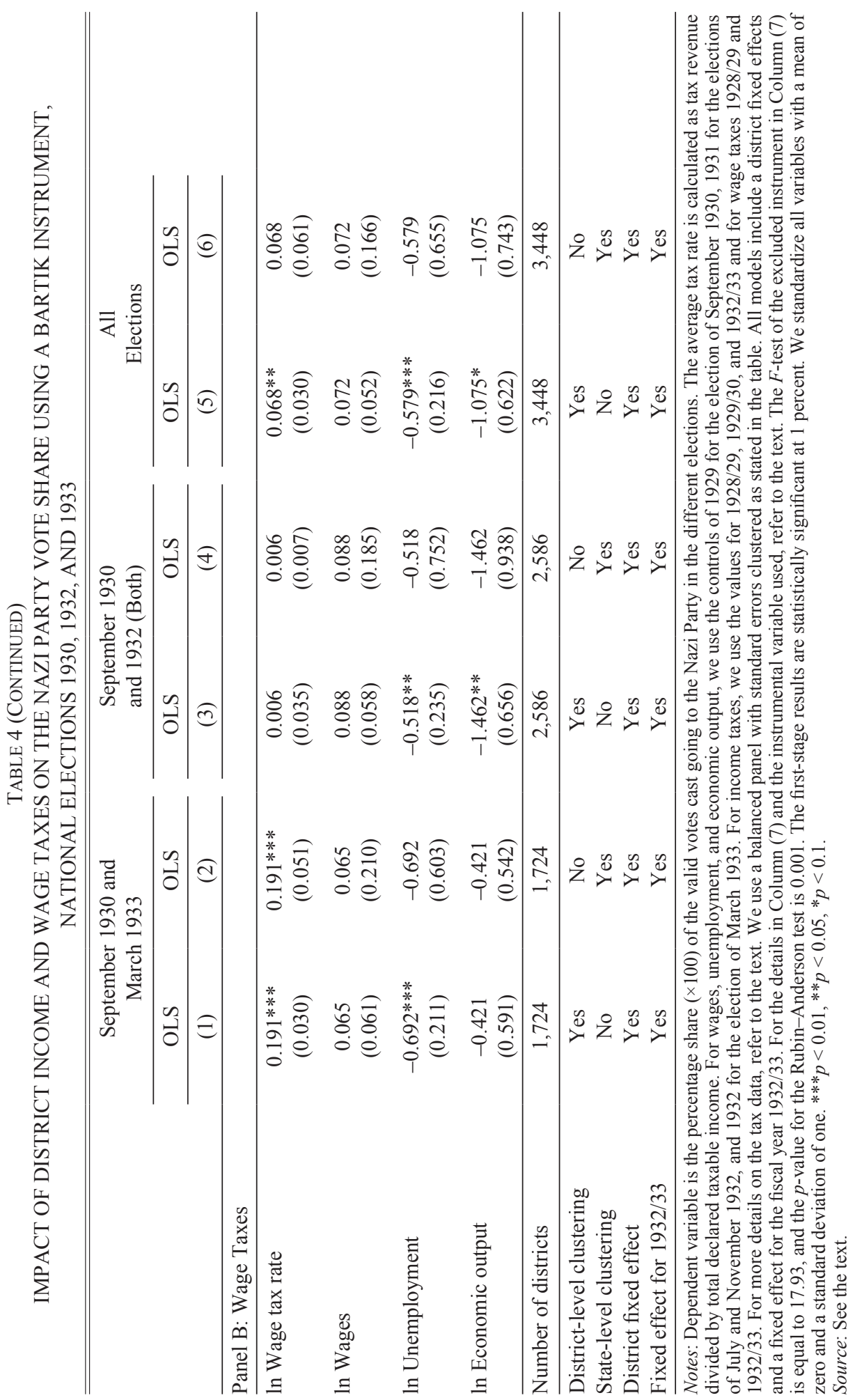


is the weighted average of statutory rates with the weights equal to the share of total taxable income within each tax bracket. Assuming constant shares, the observed percentage change in the average tax rate, denoted by $\hat{T}$ for district $d$ in period $t$, is given by

$$
\hat{T}_{d t}=\sum_{b} \omega_{d b} \hat{\tau}_{b t},
$$

where the weights, $\omega_{d b}$, are the ratio of total taxable income in bracket $b$ to total taxable income across all brackets in an initial year and $\tau_{b t}$ values are the nationally defined statutory tax rates for each bracket.

In 1930, under austerity, statutory income tax rates for each bracket were raised equally nationwide. The change in the average depends on the initial shares. As Pinkham-Goldsmith, Sorkin, and Swift (2020) show, the relevant Bartik-style instrument for this national shock to tax rates with $b$ shares and one time period is equivalent to using the initial shares as instruments. The average income tax rate in 1928 is, again, the sum of these shares (at the district level), with each share being multiplied by the same constant, $\tau_{b 1928}$ (the 1928 statutory tax rate), across all districts. We use this initial value (interacted with period fixed effects) as the excluded instrument. The first stage coefficient on the excluded instrument, the initial average income tax rate, is negative and statistically significant. The negative sign is due to the fact that the statutory tax rates rose more in proportional terms for the lowest tax brackets than the higher tax brackets.

Using the initial average income tax rate as an excluded instrument, we find a positive relationship between changes in tax rates and Nazi vote share (Column (7)). Results are not dependent on clustering at the district level or at the state level. Nevertheless, the sizes of the standardized coefficients using the instrumental variables (IV) are between two and three times larger than those using OLS, and since wage taxes were unavailable for $1929 / 30$, we cannot use this instrument for wage taxes. There is no obvious reason why the point estimate on taxes using the IV approach is so much larger than in OLS. However, there is a possibility of some heterogeneity in the impact of tax increases such that the nationally imposed tax changes had a much larger impact in certain kinds of districts.

In Table A7, we also use a differenced model. We further show that results are robust to the addition of state fixed effects, which allows for differential state-level trends and potentially mops up some of the within-state correlations in the error term. ${ }^{23}$ In Column (4), we weight the

\footnotetext{
${ }^{23}$ Results for income $(0.13$; 95 percent CI: from 0.07 to 0.19$)$ and wage taxes $(0.09 ; 95$ percent CI: from 0.04 to 0.15 ) are also statistically significant at 1 percent level of confidence using administrative division fixed effects.
} 
regressions by the level of population to emphasize the data from the larger districts and states and eliminate undue influence from smaller states. In Columns (5) and (6), we also add the lagged Nazi vote share to control for differential growth based on initial Nazi support in 1930. Lagged values refer to the election immediately prior to the latest election in the differenced dependent variable. Again, results are also very stable across specifications.

In Table A8, we explore potential heterogeneity in the impact of austerity. Here, we split the sample for values above and below the median vote share for the Nazi Party in the election of 1928 and the median values for the share of the labor force that is in agriculture, in industry, in civil service, self-employed, and in blue-collar occupations using the census data of 1925 . When we stratify the sample, we show that the impact of austerity had a larger effect in pre-1930 Nazi strongholds; in districts with a low share of blue-collar workers; in rural, agricultural, and less industrialized areas; and in localities with a higher share of civil servants and self-employed workers. It seems that austerity was a bigger determinant for those living in small towns or the countryside and those who were self-employed, rather than residents of the largest cities who were more likely to become unemployed, who turned to the Communist Party.

\section{Robustness Checks}

We pursued a number of additional robustness checks. In Figure A2, we drop one state at a time to show that our results are not driven by a particular state. In Table A9, we also study the impact of taxes on the vote shares for the main political parties. Additionally, in Table A10, we use first differences to calculate the taxes as the percentage point change (the change in the level) instead of the percentage change in average income and wage tax rates.

For another robustness check, we use a policy discontinuity design at state borders - a method which uses a potentially more relevant set of control groups. ${ }^{24}$ For each election our border district-pair data are organized to have at least two observations in each pair $p$ (one for each state in the pair). A given district appears in the data $k$ times (for each election $t$ ) if it borders $k$ districts. In total, there are 459 districts that lie along a state border, and for each border district, we match all the neighboring

${ }^{24}$ For a review of this methodology, see Dube et al. (2010), Holmes (1998), and Galofré-Vilà (2020). 
districts that are located on opposite sides of the borders, yielding a total of 1,080 border pairs. ${ }^{25}$ The district-pair match on the opposite side of a state border is a plausible control group, since while there are substantial differences in treatment intensity of austerity, due to differing statelevel policies and initial conditions, these pairs are very similar politically and economically and, approaching the border, most controls vary smoothly but the treatment variable jumps (Table A11). Hence, variation in austerity at the district level across state borders would be due to differences in state-level decisions on austerity.

Our difference-in-differences specification is as follows:

$$
\begin{gathered}
\text { NAZI }_{d t}=\alpha+\beta_{1} \ln \text { Surplus }(a)_{s t}+\beta_{2} \ln \text { Wages }_{s t} \\
+\beta_{3} \ln \text { Unemployment }_{s t}+\beta_{4} \ln \text { Output }_{s t}+\mu_{p / p t}+\delta_{t}+e_{d t},
\end{gathered}
$$

where NAZI denotes the Nazi Party vote share in district $d$ in year $t$. To unite spending and taxes in the same equation, we measure austerity as the fiscal Surplus: the logarithm of the total state income taxes paid minus the logarithm of state-level expenditure. We use income and wage taxes in alternative specifications indexed by $a$. Using a higher level of aggregation than the district for spending and taxes makes variation in treatment more plausible since state changes are determined by within-state factors. Additionally, spending data are only available at the state level. Along with the standard controls as in previous equations, we use district $\left(\mu_{d}\right)$, time fixed effects $\left(\delta_{t}\right)$, or district pair by year effects and cluster the standard errors at the state and district pair level. This level of clustering also accounts for potential mechanical spatial correlations given the presence of districts in multiple pairs. In Table 5, we provide four types of specifications according to whether we use district-pair fixed effects $\left(\mu_{p}\right)$ or district-pair fixed effects by year interactions $\left(\mu_{p t}\right)$.

We find that the variable Surplus for the border-pair sample is also positive and statistically significant. For instance, a time-varying districtpair fixed effects model using Surplus 1 gives a standardized coefficient of 0.28 (95 percent CI: from 0.15 to 0.42 ) and using Surplus 2 a coefficient of 0.23 ( 95 percent CI: from 0.06 to 0.40 ). This well-identified piece of variation, comparing neighboring districts that straddle state borders, produces consistent results with the full sample. In Table A12, we also obtain consistent results by instrumenting the percentage change in the average tax rate with the initial level of taxes paid in 1928 using districtpair and state-level clustering along with district-pair fixed effects.

\footnotetext{
${ }^{25}$ Missing data reduce somewhat the sample size from these numbers.
} 


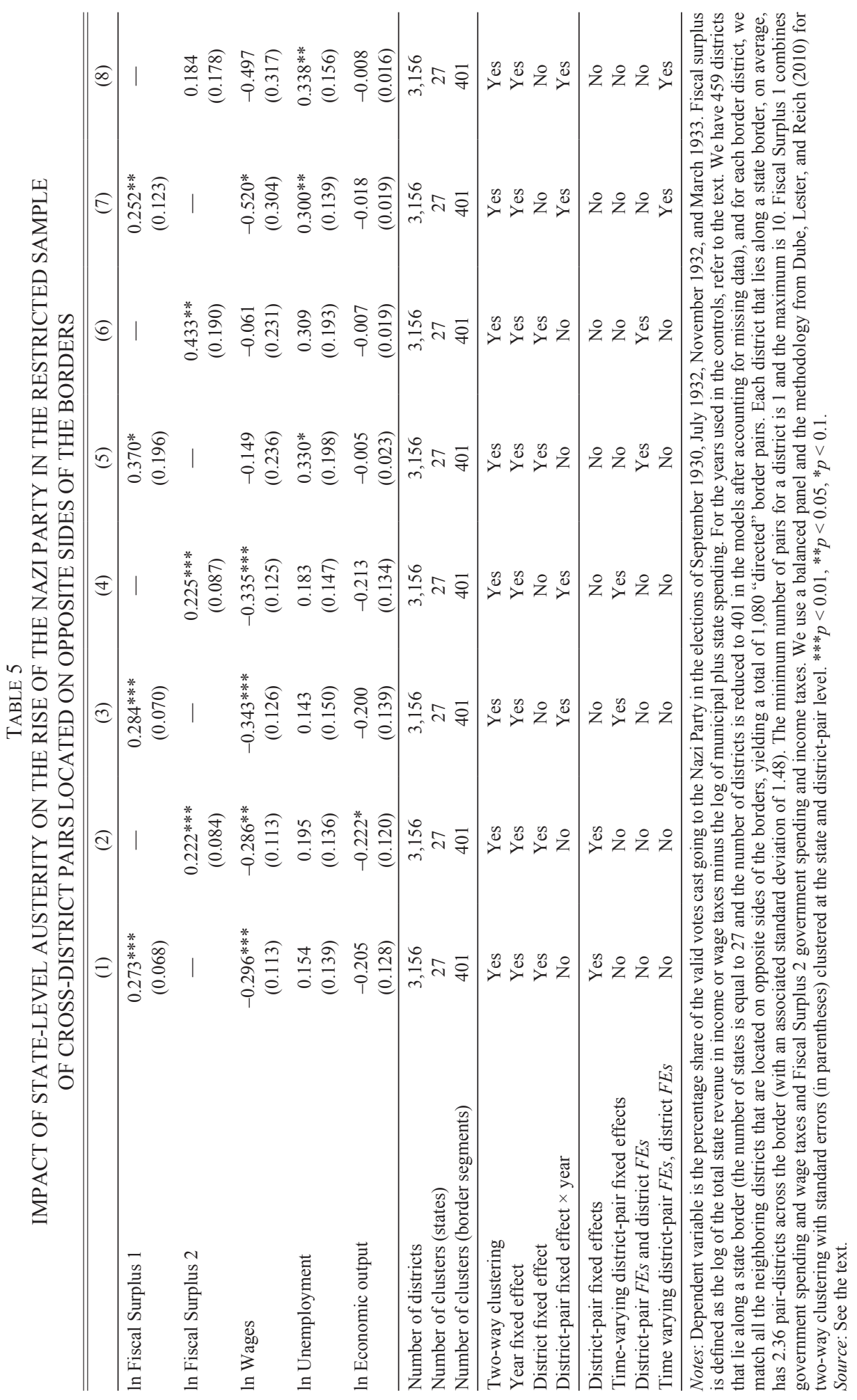




\section{CONCLUSION}

This paper offers econometric support for the idea that the austerity measures implemented between 1930 and 1932 immiserized and radicalized the German electorate. Each one-standard-deviation increase in austerity measured in several different ways was associated with between one-quarter to one-half of one standard deviation of the dependent variable. Yet, austerity is only one factor affecting the rise of the Nazi Party and there are other factors at work such as the role of German business (Ferguson and Voth 2008), the historical roots of antisemitism (Voigtländer and Voth 2012), the influence of social capital (Satyanath, Voigtländer, and Voth 2017), the banking collapse (Doerr et al. 2018), and the power of radio propaganda (Adena et al. 2015).

Austerity worsened the situation of low-income households and the Nazi Party became very efficient at channeling the austerity-driven German suffering and mass discontent. We exploit this mechanism by showing that austerity was associated with higher mortality. This reinforces the idea that, had Brüning relaxed the efforts to consolidate the budget, things might have been different.

The corollary seems clear: Even when the particular history of a country precludes a populist extreme-right option, austerity policies are likely to produce an intense rejection of the established political parties, with the subsequent dramatic alteration of the political order. The case of Weimar, explored in this paper, provides a timely example that imposing too much austerity and too many punitive conditions cannot only be self-defeating, but can also unleash a series of unintended political consequences, with truly unpredictable and potentially tragic results.

\section{REFERENCES}

Adena, Maja, Ruben Enikolopov, Maria Petrova, Veronica Santarosa, and Ekaterina Zhuravskaya. "Radio and the Rise of the Nazis in Prewar Germany." Quarterly Journal of Economics 130, no. 4 (2015): 1885-939.

Aizer, Anna. "The Gender Wage Gap and Domestic Violence." American Economic Review 100, no. 4 (2010): 1847-59.

Alesina, Alberto, Carlo Favero, and Francesco Giavazzi. Austerity: When It Works and When It Doesn't. Princeton, NJ: Princeton University Press, 2019.

Balderston, Theo. The Origins and Course of the German Economic Crisis, November 1923 to May 1932. Berlin, Germany: Haude and Spener, 1993.

Bor, Jacob. "Diverging Life Expectancies and Voting Patterns in the 2016 US Presidential Election." American Journal of Public Health 107, no. 10 (2017): 1560 62. 
Borchardt, Knut. "Wirtschaftliche Ursachen des Scheiterns der Weimarer Republik." In Weimar, Selbstpreisgabe einer Demokratie, edited by Karl Dietrich Erdmann and Hagen Schulze, 211-49. Düsseldorf: Droste, 1980.

Bromhead, Alan de, Barry Eichengreen, and Kevin H. O'Rourke. "Political Extremism in the 1920s and 1930s: Do German Lessons Generalize?" Journal of Economic History 73, no. 2 (2013): 372-406.

Büttner, Ursula. "Politische Alternativen zum Brüningschen Deflationskurs. Ein beitrag zur diskussion Uberökonomische Zwangslagen in der Endphase von Weimar." Vierteljahrshefte für Zeitgeschichte 37, no. 2 (1989): 209-51.

Chodorow-Reich, Gabriel, Laura Feiveson, Zachary Liscow, and William Gui Woolston. "Does State Fiscal Relief during Recessions Increase Employment? Evidence from the American Recovery and Reinvestment Act." American Economic Journal: Economic Policy 4, no. 3 (2012): 118-45.

Correia, Sergio. "A Feasible Estimator for Linear Models with Multi-Way Fixed Effects." Unpublished Manuscript, 2017.

Dehejia, Rajeev, and Adriana Lleras-Muney. "Booms, Busts, and Babies' Health." Quarterly Journal of Economics 119, no. 3 (2004): 1091-130.

Dell, Fabien. "Top Incomes in Germany throughout the Twentieth Century: 1891-1998." In Top Incomes over the Twentieth Century: A Contrast between Continental European and English-Speaking Countries, edited by Anthony Barnes Atkinson and Thomas Piketty. Oxford, UK: Oxford University Press, 2007.

Doerr, Sebastian, Stefan Gissler, José Luis Peydró, and Hans-Joachim Voth. "From Finance to Extremism: The Real Effects of Germany's 1931 Banking Crisis." CEPR Discussion Paper No. DP12806, Centre for Economic Policy Research, London, UK, 2018.

Dube, Arindrajit, T. William Lester, and Michael Reich. "Minimum Wage Effects across State Borders: Estimates Using Contiguous Counties." Review of Economics and Statistics 92, no. 4 (2010): 945-64.

Eichengreen, Barry. Hall of Mirrors: The Great Depression, The Great Recession, and the Uses - and Misuses - of History. Oxford, UK: Oxford University Press, 2015.

- The Populist Temptation: Economic Grievance and Political Reaction in the Modern Era. Oxford, UK: Oxford University Press, 2018.

Eichengreen, Barry, and Tim Hatton. "Interwar Unemployment in International Perspective: An Overview." In Interwar Unemployment in International Perspective, edited by Barry Eichengreen and Tim Hatton, 1-59. Dordrecht, Netherlands: Kluwer Academic Publishers, 1988.

Evans, Richard J. The Coming of the Third Reich. London, UK: Penguin Press, 2003.

Falter, Jürgen, Thomas Lindenberger, and Siegfried Schumann. Wahlen und Abstimmungen in der Weimarer Republik. Munich, Germany: C. H. Beck, 1986.

Feinstein, Charles H., Peter Temin, and Gianni Toniolo. The World Economy between the World Wars. Oxford, UK: Oxford University Press, 2008.

Feldman, Gerald D. "The Reparations Debate." Diplomacy and Statecraft 16 (2005): 487-98.

Ferguson, Niall. "Constraints and Room for Manoeuvre in the German Inflation of the Early 1920s." Economic History Review 49, no. 4 (1996): 635-66. 


\section{Galofré-Vilà, Meissner, McKee, and Stuckler}

Ferguson, Thomas, and Hans-Joachim Voth. "Betting on Hitler - The Value of Political Connections in Nazi Germany." Quarterly Journal of Economics 123, no. 1 (2008): 101-37.

Fetzer, Thiemo. "Did Austerity Cause Brexit?" American Economic Review 109, no. 11 (2019): 3849-86.

Frey, Bruno, and Hannelore Weck. "Hat Arbeitslosigkeit den Aufstieg des Nationalsozialismus Bewirkt?” Jahrbücher für Nationalökonomie und Statistik 196, no. 1 (1981): 1-31.

Fulda, Bernhard. Press and Politics in the Weimar Republic. Oxford, UK: Oxford University Press, 2009.

Galofré-Vilà, Gregori. "Quantifying the Impact of Aid to Dependent Children: An Epidemiological Framework." Explorations in Economic History 77, (2020), doi. org/10.1016/j.eeh.2020.101332.

Galofré-Vilà, Gregori, Christopher M. Meissner, Martin McKee, and David Stuckler. "The Economic Consequences of the 1953 London Debt Agreement." European Review of Economic History 23, no. 1 (2019): 1-29.

Galofré-Vilà, Gregori, Christopher M. Meissner, Martin McKee, and David Stuckler. "Replication: Austerity and the Rise of the Nazi Party." Ann Arbor, MI: Interuniversity Consortium for Political and Social Research [distributor], 2020-10-25. https://doi.org/10.3886/E125101V1.

Goebbels, Joseph. “Tondokumente und Reden: 1931-02-05, Reichstagsrede.” Internet Archive, 1931, https://archive.org/details/19310205JosephGoebbelsReichstagsred e3m21s.

Goldsmith-Pinkham, Paul, Isaac Sorkin, and Henry Swift. "Bartik Instruments: What, When, Why, and How." American Economic Review 110, no. 8 (2020): 2586624.

Gómez-León, María, and Herman J. de Jong. "Inequality in Turbulent Times: Income Distribution in Germany and Britain, 1900-50.” Economic History Review 72, no. 3 (2019): 1073-98.

Holmes, Thomas J. "The Effects of State Policies on the Location of Manufacturing: Evidence from State Borders." Journal of Political Economy 106, no. 4 (1998): 667-705.

James, Harold. The German Slump: Politics and Economics 1924-1936. Oxford, UK: Oxford University Press, 1986.

Jepsen, Charles Harold. "The Influence of the Multi-Party System on Representative Government in Germany under the Weimar Constitution (1919-1930).” Ph.D. diss., University of Oxford, 1953.

Keynes, John Maynard. The Economic Consequences of the Peace. New York, NY: Macmillan, 1920.

King, Gary, Ori Rosen, Martin Tanner, and Alexander F. Wagner. "Ordinary Economic Voting Behavior in the Extraordinary Election of Adolf Hitler." Journal of Economic History 68, no. 4 (2008): 951-96.

Nakamura, Emi, and Jón Steinsson. "Fiscal Stimulus in a Monetary Union: Evidence from US Regions.” American Economic Review, 104, no. 3 (2014): 753-92.

Newcomer, Mabel. "Fiscal Relations of Central and Local Governments in Germany under the Weimar Constitution." Political Science Quarterly 51, no. 2 (1936): $185-214$.

O’Rourke, Kevin H. "Lessons from the Great Depression.” EURO Intelligence, 2010. 
Ponticelli, Jacopo, and Hans-Joachim Voth. "Austerity and Anarchy: Budget Cuts and Social Unrest in Europe, 1919-2009." Journal of Comparative Economics 48, no. 1 (2020): 1-19.

Ritschl, Albrecht. "Reparation Transfers, the Borchardt Hypothesis and the Great Depression in Germany, 1929-32: A Guided Tour for Hard-Headed Keynesians." European Review of Economic History 2, no. 1 (1998): 49-72.

—. Deutschlands Krise und Konjunktur, 1924-1934. Binnenkonjunktur, Auslandsverschuldung und Reparationsproblem Zwischen Dawes-Plan und Transfersperre. Berlin, Germany: Akademie-Verlag, 2002.

—. "Reparations, Deficits and Debt Default: The Great Depression in Germany." In The Great Depression of the 1930s: Lessons for Today, edited by Nicholas Crafts and Peter Fearon, 110-39. Oxford, UK: Oxford University Press, 2013.

Satyanath, Shanker, Nico Voigtländer, and Hans-Joachim Voth. "Bowling for Fascism: Social Capital and the Rise of the Nazi Party." Journal of Political Economy 125, no. 2 (2017): 478-526.

Schuker, Stephen A. American "Reparations" to Germany, 1919-1933: Implications for the Third-World Debt Crisis. Princeton, NJ: Princeton University Press, 1988.

Shirer, William L. The Rise and Fall of the Third Reich: A History of Nazi Germany. New York, NY: Simon \& Schuster, 1960.

Stögbauer, Christian, and John Komlos. "Averting the Nazi Seizure of Power: A Counterfactual Thought Experiment." European Review of Economic History 8, no. 2 (2004): 173-99.

Straumann, Tobias. 1931 Debt, Crisis, and the Rise of Hitler. Oxford, UK: Oxford University Press, 2019.

Temin, Peter. "The Beginning of the Depression in Germany." Economic History Review 24, no. 2 (1971): 240-48.

- Lessons from the Great Depression. Cambridge, MA: The MIT Press, 1990.

Temin, Peter, and David Vines. Keynes: Useful Economics for the World Economy. Cambridge, MA: The MIT Press, 2014.

Voigtländer, Nico, and Hans-Joachim Voth. "Persecution Perpetuated: The Medieval Origins of Anti-Semitic Violence in Nazi Germany." Quarterly Journal of Economics 127, no. 3 (2012): 1339-92.

—. "Highway to Hitler." NBER Working Paper No. 20150, Cambridge, MA, 2019.

Voth, Hans-Joachim. "Wages, Investment, and the Fate of the Weimar Republic: A Long-Term Perspective." German History 11, no. 3 (1993): 265-92.

Wueller, Paul Hahan. "The Integration of the German Tax System." Ph.D. diss., University of Columbia, 1933. 